\title{
Application Of Realistic Mathematics Education Approach With Concrete Materials To Improve Mathematics Learning Outcomes About Solid Figures For The Fifth Grade Students Of Sdn Bangkal 01 In The Academic Year Of 2019/2020
}

\author{
1,2,3 Universitas Sebelas Maret \\ rizkyindah@student.uns.ac.id
}

Rizky Indah Tri Wahyuni ${ }^{1}$, Ngatman ${ }^{2}$, Wahyudi ${ }^{3}$

Article History

accepted 01/02/2020

approved 01/03/2020

published 01/04/2020

\begin{abstract}
:
The purposes of this study are: (1) describing the steps of applying the Realistic Mathematics Education approach with concrete materials, (2) improving mathematics learning outcomes about solid figures, and (3) describing the obstacles and solutions to the application of the Realistic Mathematics Education approach. This collaborative classroom action research was conducted in three cycles and six meetings. The research data are quantitative and qualitative data. Data collection techniques include observation, interviews and tests. The results of the study are: (1) the steps in the application of the Realistic Mathematics Education approach to improve Mathematics learning outcomes about solid figures are: a. understanding contextual problems through concrete materials, $b$. explaining contextual problems with concrete materials, $c$. resolving contextual problems with concrete materials, $d$. comparing, discussing, and answering question with concrete materials, and e. drawing conclusion; (2) the application of the Realistic Matematics Education approach can improve Mathematics learning outcomes about solid figures; (3) the obstacle in this study is students lack understanding to do worksheets, The solution is that the teacher asks the students concern to the instruction in worksheets.
\end{abstract}

Keywords: Realistic Mathematics Education, learning outcomes, Mathematics.

\section{Abstrak:}

Tujuan penelitian ini yaitu: (1) mendeskripsikan langkah-langkah penerapan pendekatan Realistic Matematics Education dengan media konkret, (2) meningkatkan hasil belajar Matematika tentang bangun ruang, dan (3) mendeskripsikan kendala dan solusi pada penerapan pendekatan Realistic Matematics Education. Penelitian tindakan kelas kolaboratif ini dilaksanakan dalam tiga siklus enam pertemuan. Data yang digunakan berupa data kuantitatif dan kualitatif. Teknik pengumpulan data menggunakan observasi, wawancara dan tes. Hasil penelitian ini yaitu: (1) penerapan pendekatan Realistic Matematics Education untuk meningkatkan hasil belajar Matematika tentang bangun ruang dilaksanakan dengan langkahlangkah : a. memahami masalah kontekstual melalui media konkret, b. menjelaskan masalah kontekstual dengan media konkret, c. menyelesaikan masalah kontekstual dengan media konkret, d. membandingkan, mendiskusikan, dan melengkapi jawaban dengan menggunakan media konkret, dan e. menyimpulkan; (2) penerapan pendekatan Realistic Matematics Education dapat meningkatkan hasil belajar Matematika tentang bangun ruang; (3) kendala dalam penelitian ini adalah masih ada siswa yang kurang memahami proses pengerjaan LKS, adapun solusi dari kendala tersebut adalah guru mengingatkan siswa untuk memperhatikan penjelasan teknik pengerjaan setelah menerima LKS.

Kata Kunci: Realistic Matematics Education, hasil belajar, Matematika.

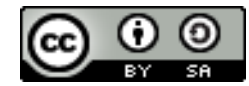

This work is licensed under a Creative Commons Attribution-ShareAlike 4.0 International License. 


\section{PENDAHULUAN}

Matematika adalah suatu bahan kajian yang di dalamnya terdapat objek abstrak serta memerlukan penalaran yang logis (Wahyudi, 2015:68).

Dalam Kurikulum 2013, Indrianti, Indriani, dan Renjani (2017: 3) mengemukakan bahwa mata pelajaran Matematika untuk kelas $\mathrm{V}$ SD/MI memuat materi-materi sebagai berikut: (1) bilangan. (2) pecahan, (3) perbandingan dan skala, (4) bangun ruang, dan (5) statistika.

Hasil belajar adalah segala perubahan yang terjadi pada diri siswa yang menyangkut pemahaman konsep, sikap, dan keterampilan proses sebagai hasil dari kegiatan belajar (Susanto, 2013: 5).

Berdasarkan hasil observasi pembelajaran Matematika di kelas $V$ dan wawancara dengan guru kelas V SDN Bangkal 01 pada hari Sabtu, 2 November 2019, peneliti menemukan bahwa proses pembelajaran Matematika di kelas V SDN Bangkal 01: (1) siswa kurang antusias, (2) guru belum menggunakan media pembelajaran, (3) hasil belajar rendah hal ini dibuktikan dengan nilai PTS (Penilaian Tengah Semester) I hanya ada $50 \%$ siswa yang mendapat nilai di atas KKM.

Berdasarkan masalah tersebut maka diperlukan solusi yaitu pembelajaran yang dapat membuat siswa belajar secara aktif, menyenangkan serta dapat menciptakan pembelajaran yang bermakna sehingga dapat meningkatkan hasil belajar siswa. Pembelajaran dengan menggunakan benda nyata atau konkret akan menambah pengalaman dan mempertajam ingatan siswa dalam memahami suatu materi. Dalam hal ini, peneliti akan menggunakan pendekatan Realistic Matematics Education dengan media konkret.

Realistic Mathematic Education (RME) adalah suatu teori dalam pendidikan Matematika yang berdasarkan pada ide bahwa Matematika adalah aktivitas manusia dan Matematika harus dihubungkan secara nyata terhadap konteks kehidupan seharihari siswa sebagai suatu sumber pengembangan dan sebagai area aplikasi melalui proses matematisasi baik horizontal maupun vertikal (Gregoria Ariyanti (Wahyudi, 2015: 24)).

Berdasarkan uraian di atas, dapat dirumuskan masalah sebagai berikut: (1) bagaimana langkah-langkah penerapan pendekatan Realistic Matematics Education dengan media konkret, (2) apakah penerapan pendekatan Realistic Matematics Education dengan media konkret dapat meningkatkan hasil belajar Matematika tentang bangun ruang pada siswa kelas V SDN Bangkal 01 tahun ajaram 2019/2020, dan (3) apakah kendala dan solusi pada penerapan pendekatan Realistic Matematics Education untuk meningkatkan hasil belajar Matematika tentang bangun ruang pada siswa kelas V SDN Bangkal 01 tahun ajaran 2019/2020. Tujuan penelitian ini, yaitu : (1) mendeskripsikan langkah-langkah penerapan pendekatan Realistic Matematics Education dengan media konkret, (2) meningkatkan hasil belajar Matematika tentang bangun ruang, dan (3) mendeskripsikan kendala dan solusi pada penerapan pendekatan Realistic Matematics Education untuk meningkatkan hasil belajar Matematika tentang bangun ruang pada siswa kelas V SDN Bangkal 01 tahun ajaran 2019/2020.

\section{METODE PENELITIAN}

Penelitian ini dilaksanakan di SDN Bangkal 01 yang berlangsung dari bulan November 2019 sampai Januari 2020. Subjek penelitian ini adalah siswa kelas V SD yang berjumlah 16 siswa yang terdiri dari 8 siswa laki-laki dan 8 siswa perempuan dan guru kelas V SDN Bangkal 01.

Data pada penelitian ini ada dua macam yaitu data mengenai penerapan pendekatan Realistic Matematics Education dengan media konkret dan data mengenai hasil belajar Matematika tentang bangun ruang. Adapun teknik pengumpulan data yang digunakan adalah observasi, wawancara, dan tes. 
Teknik uji validitas data pada penelitian ini menggunakan teknik triangulasi yaitu triangulasi teknik dan sumber. Triangulasi teknik yang digunakan yaitu observasi, wawancara, dan tes. Adapun triangulasi sumber yang digunakan yaitu siswa, guru dan dokumen. Teknik analisis data yang digunakan dalam penelitian ini yaitu reduksi data, penyajian data, dan penarikan kesimpulan sesuai model analisis data menurut Miles dan Huberman (Sugiyono, 2011: 247-253).

Indikator kinerja penelitian ini adalah penerapan pendekatan Realistic Matematics Education dengan media konkret dan peningkatan hasil belajar Matematika tentang bangun ruang $(\mathrm{KKM}=75)$ ditargetkan mencapai 85\%. Adapun prosedur penelitian ini menggunakan model penelitian tindakan kelas yang terdiri dari empat tahapan, yaitu (1) perencanaan, (2) pelaksanaan, (3) observasi, (4) refleksi.

\section{HASIL DAN PEMBAHASAN}

Penerapan pendekatan Realistic Matematics Education dengan media konkret untuk meningkatkan hasil belajar Matematika tentang bangun ruang pada siswa kelas V SDN Bangkal 01 dilakukan dalam tiga siklus. Masing-masing siklus terdiri dari dua pertemuan dengan alokasi waktu 120 menit setiap pertemuan.

Proses pembelajaran dilaksanakan dengan langkah-langkah (1) memahami masalah kontekstual melalui media konkret, (2) menjelaskan masalah kontekstual dengan media konkret, (3) menyelesaikan masalah kontekstual dengan media konkret, (4) membandingkan, mendiskusikan, dan melengkapi jawaban dengan menggunakan media konkret, dan (5) menyimpulkan. Langkah-langkah yang digunakan oleh peneliti mengacu pada langkah-langkah yang dikemukakan oleh Shoimin (2014: 150), Setyono (Wahyudi, 2015: 31), Sudia dan Kadir (2014: 608), Sudjana \& Rivai (2015: 197) yang kemudian disimpulkan menjadi langkah yang disebutkan di atas. Hasil observasi pendekatan Realistic Matematics Education dengan media konkret mengalami peningkatan pada setiap siklusnya hingga mencapaiindikator kinerja penelitian yang ditargetkan sebesar $85 \%$.

Tabel 1. Persentase Hasil Observasi pendekatan Realistic Matematics Education dengan media konkret terhadap guru dan siswa

\begin{tabular}{|c|c|c|c|c|c|c|c|c|}
\hline \multirow{2}{*}{$\begin{array}{l}\text { Langkah } \\
\text { Penerapan } \\
\text { Pendekatan } \\
R M E\end{array}$} & \multicolumn{2}{|c|}{ Siklus I } & \multicolumn{2}{|c|}{ Siklus II } & \multicolumn{2}{|c|}{ Siklus III } & \multicolumn{2}{|c|}{ Rata-rata } \\
\hline & $\begin{array}{c}\mathrm{G} \\
(\%)\end{array}$ & $\begin{array}{c}\mathrm{S} \\
(\%)\end{array}$ & $\begin{array}{c}\mathrm{G} \\
(\%)\end{array}$ & $\begin{array}{c}\text { S } \\
(\%)\end{array}$ & $\begin{array}{c}\mathrm{G} \\
(\%)\end{array}$ & $\begin{array}{l}\mathrm{S} \\
(\%)\end{array}$ & $\begin{array}{c}\mathrm{G} \\
(\%)\end{array}$ & $\begin{array}{c}\mathrm{S} \\
(\%)\end{array}$ \\
\hline $\begin{array}{l}\text { Memahami } \\
\text { masalah } \\
\text { dengan media } \\
\text { konkret }\end{array}$ & 87,50 & 86,67 & 89,16 & 91,67 & 95,83 & 95,83 & 90,83 & 91,39 \\
\hline $\begin{array}{l}\text { Menjelaskan } \\
\text { masalah } \\
\text { dengan media }\end{array}$ & 88,54 & 87,50 & 90,62 & 90,62 & 94,79 & 94,79 & 91,32 & 90,97 \\
\hline $\begin{array}{l}\text { Menyelesaikan } \\
\text { masalah }\end{array}$ & 87,50 & 87,50 & 91,67 & 91,67 & 95,83 & 95,83 & 91,67 & 91,67 \\
\hline $\begin{array}{l}\text { Membandingk } \\
\text { an dan } \\
\text { mendiskusikan }\end{array}$ & 88,15 & 86,10 & 88,88 & 86,45 & 93,74 & 92,35 & 90,25 & 88,30 \\
\hline Menyimpulkan & 88,09 & 87,50 & 89,87 & 88,68 & 94,04 & 94,04 & 90,67 & 90,07 \\
\hline Rata-rata & 87,96 & 87,05 & 90,04 & 89,82 & 94,85 & 94,57 & 90,95 & 90,48 \\
\hline
\end{tabular}

Berdasarkan tabel di atas, diketahui bahwa proses pembelajaran di siklus I, siklus II, dan siklus III selalu mengalami peningkatan. Hasil capaian guru dalam mengajar pada siklus I yaitu $87,96 \% \%$, pada siklus II $90,04 \%$ dan pada siklus III $94,85 \%$ Hasil capaian siswa dalam pembelajaran pada siklus I yaitu $87,05 \%$, pada siklus II yaitu $89,82 \%$, dan pada siklus III mencapai $94,57 \%$. 
Tabel 2. Analisis Hasil Belajar Siswa Siklus I, II, dan III

\begin{tabular}{lcccccc}
\hline \multirow{2}{*}{ Keterangan } & \multicolumn{2}{c}{ Sikkus I } & \multicolumn{2}{c}{ Siklus II } & \multicolumn{2}{c}{ Siklus III } \\
\cline { 2 - 7 } & Pert. 1 & Pert.2 & Pert.1 & Pert.2 & Pert.1 & Pert.2 \\
\hline Nilai Tertinggi & 100 & 100 & 100 & 100 & 100 & 100 \\
\hline Nilai Terendah & 73,00 & 67,00 & 67,00 & 73,00 & 77,00 & 80,00 \\
\hline Rata-rata & 84,31 & 87,31 & 87,50 & 88,31 & 93,00 & 94,18 \\
\hline Tuntas & 14 & 14 & 14 & 15 & 16 & 16 \\
\hline Belum Tuntas & 2 & 2 & 2 & 1 & 0 & 0 \\
\hline
\end{tabular}

Berdasarkan tape a atas, aapat aıketanuı panwa ketuntasan hasil belajar siswa selalu mengalami peninggkatan di setiap siklus. Pada siklus I persentase ratarata siswa yang tuntas yaitu $87,50 \%$, pada siklus II $90,62 \%$, dan pada siklus III $100 \%$. Hasil akhir pada siklus III sudah mencapai target yang ditentukan.

Dengan demikian penerapan pendekatan Realistic Matematics Education dengan media konkret dapat meningkatkan hasil belajar Matematika tentang bangun ruang yang dilihat dari persentase siswa yang memenuhi ketercapaian target dari siklus I-III. Hasil penelitian ini memperkuat penelitian yang dilakukan oleh Mulyanto (2007: 1) yang menunjukan bahwa pendekatan $R M E$ dapat efektif meningkatkan kemampuan pemahaman operasi bilangan bulat negatif pada pembelajaran matematika di kelas IV. Hal ini juga dilakukan oleh Fitriani \& Maulana (2016: 40) yang menjelaskan bahwa pembelajaran dengan penggunaan Pendekatan $R M E$ dapat meningkatkan kemampuan pemahaman dan pemecahan masalah matematis siswa SD kelas $\mathrm{V}$.

Kendala penerapan pendekatan Realistic Matematics Education (RME) dengan media konkret untuk meningkatkan hasil belajar Matematika tentang bangun ruang pada siswa kelas V SDN Bangkal 01 tahun ajaran 2019/2020 yaitu : (1) masih sedikit siswa yang berani bertanya, (2) siswa kurang aktif menanggapi diskusi, (3) siswa ramai sendiri, (4) waktu diskusi terbatas, (5) ada siswa yang menyalahgunakan media, (6) siswa kurang memperhatikan guru, dan (7) siswa langsung berdiskusi sebelum dijelaskan. Adapun solusi untuk mengatasi kendala tersebut yaitu : (1) guru merangsang siswa untuk bertanya, (2) mengarahkan siswa untuk saling menanggapi diskusi, (3) meningkatkan penguasaan kelas, (4) mengarahkan siswa berbagi tugas, (5) guru memberikan teguran, (6) guru menegur siswa untuk memperhatikan guru, (7) guru mengingatkan siswa untuk memperhatikan guru setelah menerima LKS.

\section{SIMPULAN DAN SARAN}

Penerapan pendekatan Realistic Matematics Education dengan media konkret untuk meningkatkan hasil belajar Matematika tentang bangun ruang pada siswa kelas V SDN Bangkal 01 tahun ajaran 2019/2020 dilaksanakan dengan langkah-langkah: (1) memahami masalah kontekstual melalui media konkret, (2) menjelaskan masalah kontekstual dengan media konkret, (3) menyelesaikan masalah kontekstual dengan media konkret, (4) membandingkan, mendiskusikan, dan melengkapi jawaban dengan menggunakan media konkret, dan (5) menyimpulkan.

Penerapan pendekatan Realistic Matematics Education dengan media konkret dapat meningkatkan hasil belajar Matematika tentang bangun ruang pada siswa kelas V SDN Bangkal 01 tahun ajaran 2019/2020, ditunjukkan dengan peningkatan persentase siswa pada setiap siklus yang memenuhi ketercapaian target indikator penelitian sebesar $85 \%$.

Kendala penerapan pendekatan Realistic Matematics Education (RME) dengan media konkret untuk meningkatkan hasil belajar Matematika tentang bangun ruang 
pada siswa kelas V SDN Bangkal 01 tahun ajaran 2019/2020 yaitu : (1) masih sedikit siswa yang berani bertanya, (2) siswa kurang aktif menanggapi diskusi, (3) siswa ramai sendiri, (4) waktu diskusi terbatas, (5) ada siswa yang menyalahgunakan media, (6) siswa kurang memperhatikan guru, dan (7) siswa langsung berdiskusi sebelum dijelaskan. Adapun solusi untuk mengatasi kendala tersebut yaitu : (1) guru merangsang siswa untuk bertanya, (2) mengarahkan siswa untuk saling menanggapi diskusi, (3) meningkatkan penguasaan kelas, (4) mengarahkan siswa berbagi tugas, (5) guru memberikan teguran, (6) guru menegur siswa untuk memperhatikan guru, (7) guru mengingatkan siswa untuk memperhatikan guru setelah menerima LKS.

Berkaitan dengan hasil penelitian yang telah dicapai, peneliti mengajukan saran sebagai berikut: (1) siswa hendaknya lebih bersemangat lagi dan berani untuk mengemukakan pendapatnya dalam menanggapi kelompok lain ataupun bertanya jawab mengenai hal yang belum dipahami dari materi yang dipelajari untuk mendapatkan hasil yang maksimal, (2) guru lebih memperhatikan langkah pendekatan $R M E$ dengan media konkret dan lebih meningkatkan kemampuan merangsang siswa untuk bertanya supaya siswa lebih aktif dalam kegiatan pembelajaran, (3) sebaiknya sekolah menyediakan fasilitas, sarana, dan prasarana serta mendukung guru untuk berinovasi dalam menggunakan pendekatan atau model dan media pembelajaran untuk meningkatkan kualitas pembelajaran, dan 4) peneliti lain hendaknya membuat kegiatan pembelajaran yang lebih inovatif dan kreatif sesuai dengan perkembangan ilmu pengetahuan yang semakin maju. Salah satunya, yaitu dengan menerapkan pendekatan Realistic Matematics Education (RME).

\section{DAFTAR PUSTAKA}

Fitriani, K., \& Maulana, M. (2016). Meningkatkan Kemampuan Pemahaman Dan Pemecahan Masalah Matematis Siswa Sd Kelas V Melalui Pendekatan Matematika Realistik. Mimbar Sekolah Dasar, 3(1), 40-52. Diperoleh pada 3 November 2019, dari http://ejournal.upi.edu/index.php/mimbar /article

Indrianti, M, Indriani, I, \& Renjani, N.A. (2017b). Buku Guru Matematika untuk Kelas V SD/MI. Klaten : Intan Pariwara.

Mulyanto, R. (2007). Pendekatan RME untuk meningkatkan pemahaman operasi pengurangan bilangan bulat negatif pada pembelajaran matematika di SDN Sukalerang I Kabupaten Sumedang. Jurnal Pendidikan Dasar, 1(8), 1-4. Diperoleh pada 2 November 2019, dari http://file.upi.edu /Direktori/JURNAL/PENDIDIKAN_DASAR/Nomor_8Oktober_2007/

Shoimin, A. (2014). 68 Model Pembelajaran Inovatif dalam Kurikulum 2013. Yogyakarta: Ar-Ruzz Media

Sudia, M \& Kadir. (2014). Developing Skills Resolution Mathematical Primary School Students. International Journal of Education and Research. 2 (10). 601-614. Diperoleh pada 3 November 2019 dari http://www. ijern. com/journal/2014/October-2014/48

Sudjana, N \& Rivai, A. (2015). Media Pengajaran. Bandung: Sinar Baru Algensindo.

Sugiyono. (2009) Metode Penelitian Kuantitatif Kualitatif dan R\&D. Bandung: Alfabeta.

Susanto, A. (2013). Teori Belajar \& Pembelajaran di Sekolah Dasar. Jakarta: Prenada Media Grup.

Wahyudi. (2015). Panduan Pembelajaran Matematika Sekolah Dasar (Untuk Guru Calon Guru SD). Surakarta: UNS Press. 